\title{
The Annual of the British School at Athens
}

http://journals.cambridge.org/ATH

Additional services for The Annual of the British School at Athens:

Email alerts: Click here

Subscriptions: Click here

Commercial reprints: $\underline{\text { Click here }}$

Terms of use : $\underline{\text { Click here }}$

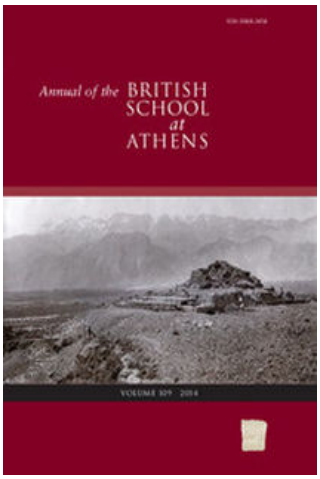

\section{Heraldry of the Rhodian Knights, formerly in Smyrna Castle}

\author{
F. W. Hasluck
}

The Annual of the British School at Athens / Volume 17 / November 1911, pp 145 - 150

DOI: 10.1017/S0068245400008546, Published online: 18 October 2013

Link to this article: http://journals.cambridge.org/abstract_S0068245400008546

How to cite this article:

F. W. Hasluck (1911). Heraldry of the Rhodian Knights, formerly in Smyrna Castle. The Annual of the British School at Athens, 17, pp 145-150 doi:10.1017/ S0068245400008546

Request Permissions : $\underline{\text { Click here }}$ 


\section{HERALDRY OF THE RHODIAN KNIGHTS, FORMERLY IN SMYRNA CASTLE.}

THE two white marble slabs shewn below (Figs. 2, 3), originally in the castle of S. Peter at Smyrna, are now built into the circular court of the prison, high up, facing the entrance from the street. I was first apprised of their whereabouts by the late Dr. Weber, who himself published them

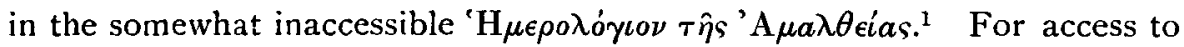
the prison I am indebted to the kindness of Mr. E. Harris, Consul-General of the United States.

The history of the castle need not long occupy us here. ${ }^{2}$ It is sufficient to say that it dated from the capture of Smyrna in I344 by a combined Christian fleet under Jean de Biandra, Prior of Lombardy, and was held by the Papacy till I374, when it was transferred to the Knights of S. John (Grand Master de Julliac) by Gregory XI. In 1392 it was repaired for the Order by Domenico d'Allemagna, Admiral of Rhodes, at the charges of G. M. de Heredia, ${ }^{3}$ again by G. M. de Naillac in ${ }^{1} 398$, and finally stormed by Timur in I 399. ${ }^{4}$ It was never recovered by the Knights, who are said to have built the new castle of $S$. Peter (Budrum) to replace it as a mainland stronghold. ${ }^{5}$

Timur is said to have razed the castle to the ground, ${ }^{6}$ but a fort

${ }^{2}$ 1894, pp. $150-154$.

2 The best view of its history is given by Mas-Latrie, Trísor de Chronologie, $1789 \mathrm{f}$ : : see also Bosio, Vertot, and Tomaschek in Sitzb. Akad. Wien, cxxiv. (1891), p. 27. (82)).

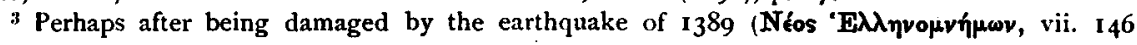

4 So Muralt : others place the capture in 1398 (Bosio) and 1404 (Sherif-ed-din).

5 For the date of the building of Budrum, Bosio gives 1399 , Buondelmonti 1400 (map of Kos).

- Theod. Niemius, de Schismate, ii. xxx.: Castrum solo coaequavit, adeo quòd etiam, ut ipsimet fratres dicti hospitalis aiunt cum $\mathrm{C}$ milibus forenoram auri in statum pristinum reduci non tosset. 
occupying the old position (at the entrance to the ancient closed port) is mentioned by successive travellers from the early seventeenth century down to our own day ${ }^{1}$ (Fig. I). Its age was to some extent guaranteed by the Christian arms left in situ and Mas-Latrie believed it to be of Latin

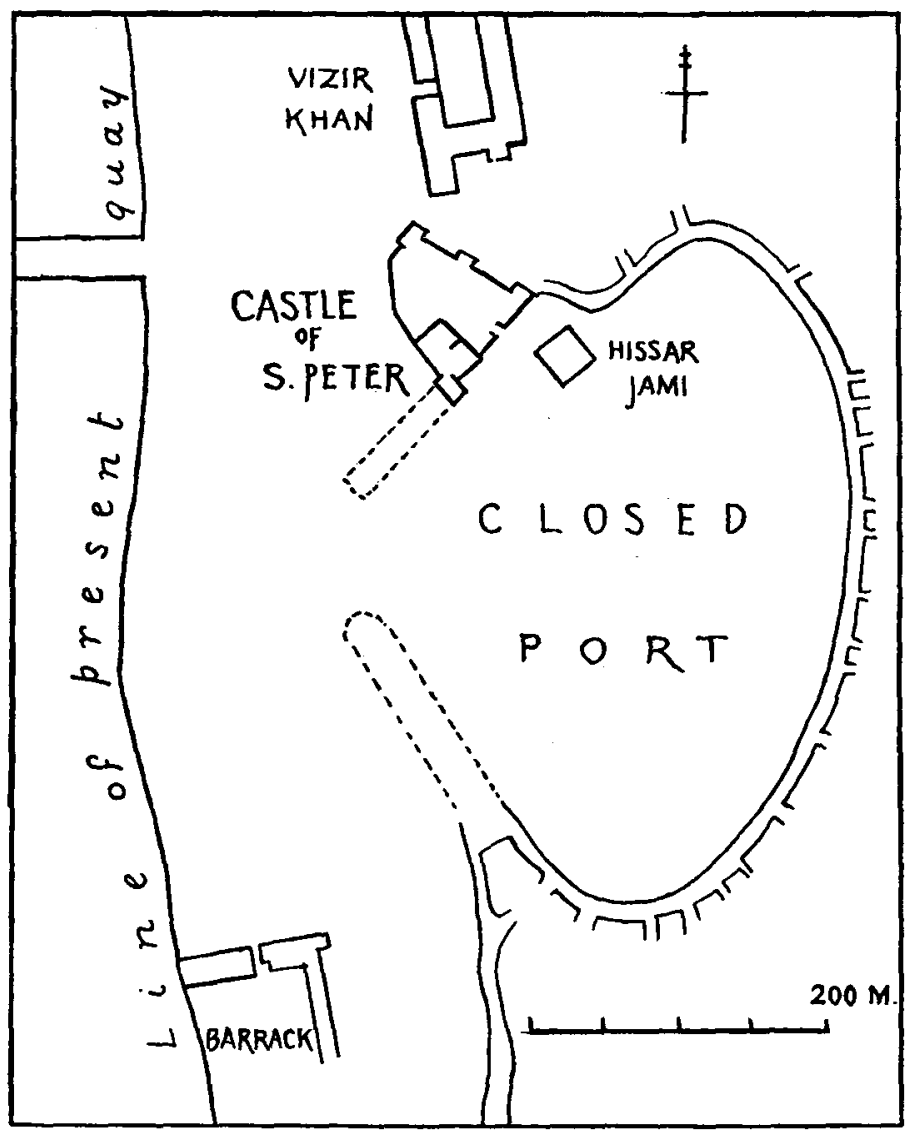

Fig. I.-Sketch-Plan of Castle of S. Peter and Environs.

construction except the battlements, which are shewn by Flandin's drawing to have been 'swallow-tailed' as at Rhodes. The plan of the castle appears to have been triangular, each side measuring about

1 D'Arvieux (1654), i. 53 ; Thévenot, i. 289; Le Bruyn ; Earì of Sandwich, 307 ; Hobhouse, i. 620; Arundell, Asia Minor, ii. 40I; Prokesch, Wiener Jahrbiucher f. Litteratur, A nzeigerblatt 67 (1834), 65; Mas-Latrie, Rev. Miss. Arch. (1850), 104. 
100 metres, with walls twenty-five feet high, flanking towers, and an

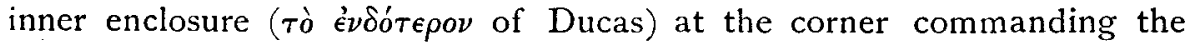
mouth of the harbour. ${ }^{1}$ Some idea of its appearance is given by the drawings of Le Bruyn, Tournefort, La Borde, ${ }^{2}$ and Flandin. ${ }^{3}$ It ceased to be of importance after the building of Sanjak Kaleh (c. 1650) and was probably dismantled about this date. It was not demolished till 1872 , being then full of Turkish houses. ${ }^{4}$

The ancient port adjoining the castle served as a harbour and drydock for galleys and small native craft in the seventeenth and eighteenth

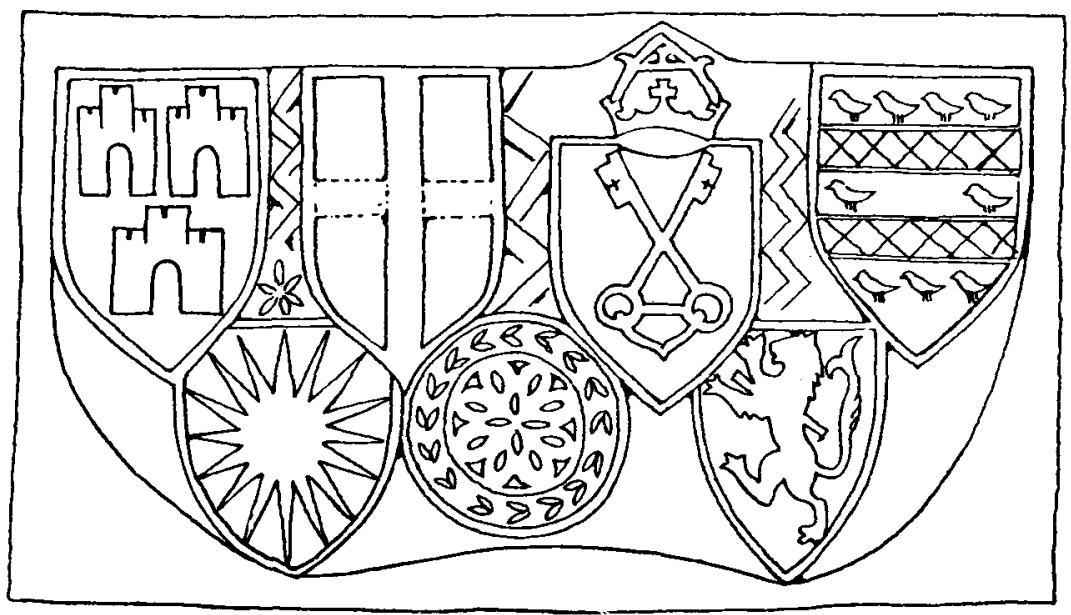

Fig. 2.-Arms from Castle of S. Peter, Smyrna (No. i).

centuries, but gradually silted up. In I62 I large vessels could still enter it, ${ }^{5}$ but in Cliandler's time it was dry except after very heavy rains, and in 1834 the whole of the ground was built over. ${ }^{6}$ A small pool, probably an open drain, marks the last trace of the harbour in the English charts of 1844 .

The arms of the Papacy over the seaward gate of the castle have been noted by several travellers. ${ }^{7}$ Of these the most explicit is Mas-Latrie, who

${ }^{1}$ Weber, loc. cit. $\quad{ }^{2}$ Voy. en Asie Mineure, Pl. III. p. 7. $\quad{ }^{3}$ L'Orient, i. PI. XLVII.

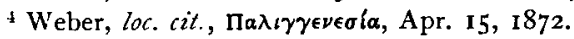

DDes Hayes, 343 : cf. de Burgo's account in I680 (Viaggio, i. 459).

${ }^{6}$ Arundell, loc, cit.

' D'Arvieux, i. 53; Thévenot, i. 289 ; Arundell, ii. 401 ; Mas-Latrie, Rev. des Miss. i. (1850) I04 $=$ Bibl. Ec. des Chartes, IIs. ii, 560 . 
saw there in 1845 a marble slab with three shields, recognizable from his description as identical with our slab (2) (Fig. 3). Beside this was a second (which has since disappeared) with two shields, one charged with three rows of isolated towers (tourelles), the other circular with a charge resembling a wheel. Treo blocks are noted in the same position by Arundell, so there can be no question of confusion with our slab (I) (Fig. 2).

In discussing the heraldry of the two slabs, the second may be neglected, as all the arms in it occur also in the first. It may be remarked that (2) is rather better than (1) in workmanship, especially in the decora-

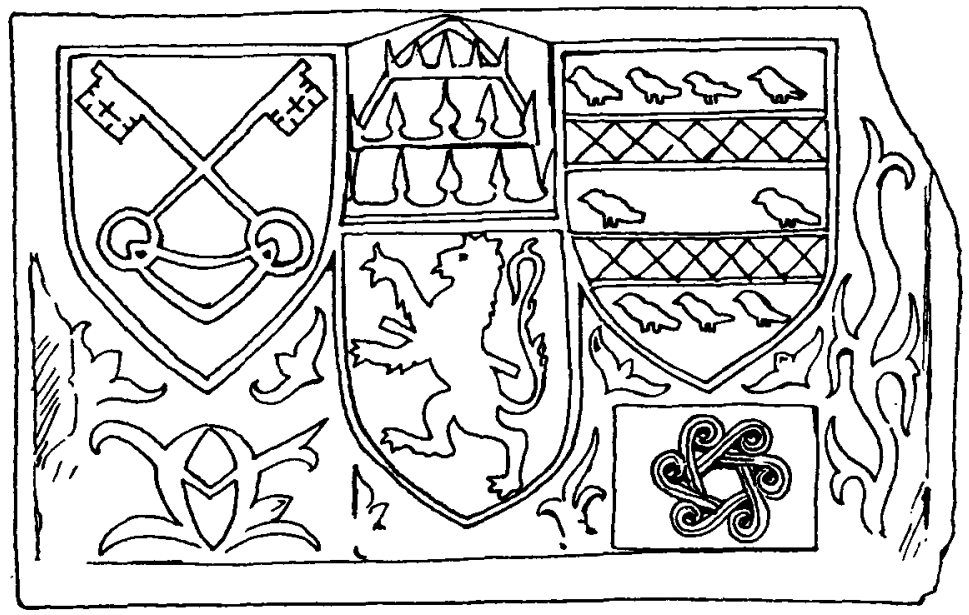

Fig. 3. - Arms from Castle of S. Peter, Smyrna (No. 2).

tion, which resembles the ordinary Genoese work of the period, that of (I) being crude and childish in the extreme. ${ }^{1}$

The arms shewn on block ( 1 ) (Fig. 2) are as follows (left to right) :-

(1) de Heredia, (2) Order of S. John, (3) Papacy, (4) d'Allemagna, (5) des Baux (?), (6) -

(1) Ferdinand de Heredia was Grand Master 1376-1 396. The arms should be, $g u$. seven towers, $\arg .3,3$, and $\mathrm{I}^{2}$ The variation is accounted

1 The dimensions of the blocks as given by Weber are $1.04 \times 0.50 \mathrm{~m}$. and $1.00 \times 0.70 \mathrm{~m}$. respectively. I was unable to reach them.

2 They are, however, blazoned in various ways; at Rhodes we find in two cases seven towers arranged 2, I, 2, I, I (Belabre, Rhodes, p. 47, Fig. 28, p. 164, Fig. 167), once five towers, 2, 1, 2 (ibid. p. 89, Fig. 73). In the castle of Kos, three castles, two and one, the castles three-towered as here. 
for by the inferior workmanship of the stone; we have seen that the correct bearing was given in the missing stone.

(2) In the second shield the cross has been intentionally defaced by the Turks.

(4) These arms commemorate Domenico d'Allemagna who repaired the fortifications in 1392 and was to some extent responsible for the work done under de Naillac in $1398 .^{1}$ Combined with the arms of de Heredia they satisfactorily fix the date of both slabs. Though not the arms assigned to d'Allemagna by de Goussancourt ${ }^{2}$ they are described exactly by Campanile, ${ }^{3}$ who comments on the variety of arms borne by this family. They also occur several times at Rhodes :-

(a) formerly on the harbour walls (old post of Italy) with the arms of de Heredia and a coat bearing three nails, also (a later addition?) the arms of de l'Isle Adam as Grand Master, and others : ${ }^{4}$

(b) formerly on the gate of $S$. Nicolas with the arms of de Heredia and the three nails. ${ }^{5}$

These probably date from the last years of de Heredia, when d'Allemagna acted for him in Rhodes.

(c) Formerly in the hospital of S. Catharine, patroness of the Italian Langue. ${ }^{6}$ D'Allemagna is known to have founded the chapel of S. Catharine with a hostel used for entertaining distinguished guests. ${ }^{7}$

(d) on a relief of the Virgin now preserved in the Latin Church. ${ }^{8}$ D'Allemagna is known to have built a chapel of the Virgin in the conventual church. ${ }^{9}$

'Bosio, ii. 111. The repairs were carried out by Buffillo Panizzato, prior of Barletta.

2 Martyrologie (Paris, I643), P1. IX.

${ }^{3}$ Delle Arme overo instigne dei Nobili (Napoli, 1618 ) p. 220, ' . . il campo d'oro con le (due) fascie vermiglie couerte d'alcuni reti d'argento, con otto o noue uccelli vermigli . .' I owe this reference to the kindness of Mr. A. van de Put. Picenardi and Belabre identify the arms with Chantemerle.

${ }^{4}$ Rottiers, Pls. IX. XI. A. Berg, p. 36. The birds are here arranged in orle 4, 2 , and 3 .

"Belabre, p. 47, Fig. 28. (Similar arrangement but not in orle.)

${ }_{6}$ 1bid. p. 147, Fig. 147. The birds are here placed 3, 3, and 3 with a chief of the order.

7 N. de Martoni (1395) in Rev. Or. Lat. iii. 682 ; Bosio, ii. I02; Belabre, 146.

${ }^{8}$ Chateaubriand, Itinteraire, 211 ; Rottiers, Il. XX.; Picenardi, I55; Belabre, p. 163, Fig. 165: the birds are here in orle, 4,2 , and 3 . The modern inscription may replace a chief of the order.

${ }^{9}$ Bosio, ii. I02 (1392). D'Allemagna's career is thus : Commander of Naples, I386; held Nisyros for the Order, 1386-92 (Bosio, ii. 196, ro2-3, ef. Martoni, 642); Admiral, 1392-8 (Bosio, ii. 128); Lieutenant for the Grand Master (Bosio, ii. 122); Commander of Naples, S. Stefano, Avignon, Nocera, and Fineca, 1407; died Bailly of Lango, 1410 (Bosio, 128-31). 
(5) The Provençal family of Des Baux, several members of which joined the Order, bore $g u$, a star of sixteen rays $a r g .{ }^{1}$ But the wheel of S. Catharine may have been intended here as in the lost block described by Mas-Latrie.

(3) Though in No. 2 these arms are ensigned with the tiara and should be those of a pope (presumably Clement VI. of Avignon who actively assisted the building) they agree with no pope's arms between 1344 and 1404 as given by Ciacconi.

F. W. HASLUCK.

'Campanile, lor. cit. p. 143 . 